Article

\title{
Financial Inclusion in Ethiopia: Is It on the Right Track?
}

\author{
Tekeste Berhanu Lakew ${ }^{1}$ and Hossein Azadi ${ }^{2,3,4, *(D)}$ \\ 1 Department of Accounting and Finance, College of Business and Economics, Mekelle University, \\ 231 Mekelle, Ethiopia; tekeste.berhanu@mu.edu.et \\ 2 Department of Geography, Ghent University, 9000 Ghent, Belgium \\ 3 Research Group Climate Change and Security, Institute of Geography, University of Hamburg, \\ 20144 Hamburg, Germany \\ 4 Faculty of Environmental Sciences, Czech University of Life Sciences Prague, 16500 Prague, Czech Republic \\ * Correspondence: hossein.azadi@ugent.be; Tel.: +32-(0)9-264-46-95; Fax: +32-(0)9-264-49-85
}

Received: 17 October 2019; Accepted: 13 April 2020; Published: 2 May 2020

check for updates

\begin{abstract}
It is important to evaluate the impact of Ethiopia's financial inclusion strategy since it has been launched in 2014. Accordingly, this paper assesses the extent to which the target has been met. The main aim of this study is to measure the success or failure of Ethiopia's financial inclusion in comparison with other countries in East Africa. Using secondary data, this study revealed that Ethiopia's financial inclusion is not as successful as other East African countries. This study also found that Ethiopians prefer informal saving clubs rather than formal financial organs. This preference, combined with unemployment and low income, is the barrier to the financial inclusion strategy. Based on the findings, identifying and addressing root causes should be done by removing distance, cost, credit, and documentation barriers. Moreover, the findings showed that access to public transit can also expand the reach of formal financial institutions by encouraging more people to physically access financial institutions. This study recommended access to formal financial organs as a core to financial institutions. Access to formal financial organs should be boosted through increasing financial institutions. Educating individuals about their financial circumstances were also recommended so that people can increase their formal saving uptake. This paper also recommended that the government develop regulatory guidelines for the functioning of financial institutions. The main outcome, therefore, is that financial institutions could be more transparent and predictable, reduce costs, and simplify the rules for entering the market.
\end{abstract}

Keywords: microfinance; formal financial system; financial exclusion; East Africa

\section{Introduction}

It is believed that Ethiopia has never been colonized, and Ethiopians are proud of possessing ancient alphabets and numbers. Most of all, they are proud of their traditional financial system called 'iqub' and 'edir/mahiber. Ethiopians say, "sewin sew yaregew iqub ne' w" which means "a human is human because of iqub". Average employees save from 20 to 300 ETB per week and 1000 to 10,000 ETB for companies. While most employees do this on a monthly basis, people also save on a daily basis. The Iqub money is used only in situations such as weddings, funerals, and sickness, while it circulates among members regularly. The members shall determine how much money the publisher should contribute to the needy member (Allen et al. 2016).

The formal financial system in Ethiopia is extremely underdeveloped and confined mainly to cities and larger towns (Dinku 2019). Despite strong efforts by banks to offer formal financial products to attract clients and offer new financial services, financial inclusion in Ethiopia FDIP (Efina 2016) has a long 
way to go, as the country was ranked the last second in terms of financial inclusion among 26 politically, geographically, and economically identical countries. In 2014, only $7.4 \%$ of adults in sub-Saharan African countries used formal credit at the financial institution, while $18 \%$ used it in high-income economies, and mobile banking in Africa is at a leading position (Demirguc-Kunt et al. 2015).

Many developing countries have acknowledged using financial inclusion strategies since 2010 (Baza and Rao 2017). According to the World Bank (2014a, 2015) database, 1.2 billion adults have opened accounts since 2011, while 515 million of them have opened accounts since 2014. From 2014 to 2017 , adults who accessed accounts using a mobile banking service globally rose from $62 \%$ to $69 \%$. In developing economies, the number rose from $54 \%$ to $63 \%$. However, in developing economies, the percentage of women remains 9\%. In sub-Saharan Africa, women are not encouraged to do business due to cultural barriers, but mobile banking services drove financial inclusion in countries of sub-Saharan Africa (Demirguc-Kunt et al. 2015).

Ethiopia is, however, lagging behind its neighbors. For instance, $82 \%$ of adults own accounts in Kenya, 50\% in Rwanda, and $43 \%$ of adults have an account in the region. Only less than one-quarter of adults in Ethiopia have a formal account. Some private and public bankers could argue that ownership of formal accounts is increasing (Adeola and Evans 2017).

The main reason why financial institutions in Ethiopia do not have a bank account is the lack of funds and the fact that financial institutions are too far away, while religious reasons and lack of trust in financial institutions are the least. Beck and Cull (2015) note that African banking systems are less inclusive than non-African ones. $16.5 \%$ of households in a medium-sized African country report having an account with a financial institution. Only $10 \%$ of households in Ethiopia have access to formal credit, of which only $1 \%$ of the rural population has a bank account. Based on the findings of Dinku (2019), the main reason that more than $85 \%$ of adults (15+) in Ethiopia do not have a bank account or any other financial institutions is insufficient fund, and the other reason that hinders access to a bank account is that financial institutions are too far away from them. However, religious reasons and lack of trust in formal financial institutions are the least.

Therefore, there is a need for an efficient transaction theory to consider related party transactions towards meeting the economic needs of both the individuals and the banks. This is because both parties have the ability to freely share their ideas and requirements and to have a trust-based relationship. Thus, this theory does not consider related party transactions to be harmful to shareholders. Another strategy could be placing the banks in different locations to cover all neighborhoods and enhancing the access (Dinku 2019).

It should be indicated that access to formal financial services makes financial transactions efficient and secure for people and helps poor people to overcome poverty through investment in education and business. Formal financial integration can also prevent individuals from falling into poverty by providing ways to handle income shocks like unemployment or losses of money launderers (Demirguc-Kunt et al. 2015). Formal financial services are also more beneficial to society. Shifting payment from cash to account makes payments from governments or companies to people and from individuals to governments or organizations more productive and transparent (Sahay et al. 2015). Formal financial services will contribute towards reducing poverty and inequality by helping people save and control their financial risk in the future. There are a number of financial services for individuals around the world and across all revenue categories. Many low-income adults, however, rely on informal financial services (Collins et al. 2009).

Therefore, this study contributes to identifying factors that significantly affect the long-term survival and viability of formal financial inclusion and to demonstrating the strategic importance of Iqub schemes to ensure sustainable growth and development of financial institutions in Ethiopia. Moreover, this study contributes to addressing the following questions: (1) why do some people own accounts and others are excluded?; (2) why do some Ethiopians use their accounts to save on a formal basis or to make and receive payments, and others not?; (3) what is a gender gap and why does it exist in the Ethiopian financial inclusion system?; (4) what are the main barriers to inclusion systems?; (5) how and to what extent requirements for market entry and financial services could be enhanced? 


\section{Literature Review}

\subsection{Theoretical Literature}

Distribution of financial institutions, openness of or access to these distributed financial institutions, and usage of the services offered by the financial institutions are the three important dimensions of financial inclusion or exclusion. Sarma and Pais (2008) stated that the financial inclusion mechanism ensures that all entrepreneurs have easy access to and use the formal financial system. Therefore, financial inclusion can be redefined to raise awareness of financial systems, improve access and transparency, and ensure that all sectors of society benefit from basic financial products and services. This definition has been used as a guideline throughout this report, but financial inclusion and exclusion must be further explored in order to fully understand the concept (European Commission 2008). According to the report ${ }^{1}$ by the Center for Financial Inclusion at Accion in 2018, financial inclusion has acknowledged the role it plays in creating positive changes in economic and social development, including many of the Sustainable Development Goals. This report states that electronically parking school fees or bills and such indicators provide certain insights into improved financial inclusion for those who are new to the formal financial system. Building on the recognition that the fundamental aim of financial services is to encourage people to do more about their resources, the ultimate objective of financial inclusion is to improve their lives. Well-functioning financial services serve as a vital financial purpose by offering savings, payment, consumer protection, credit, and risk management systems to individuals and firms (Mlachila et al. 2016). Financial inclusion generally means that everyone has access to financial services at an affordable price, but it depends on how well the region has changed, as well as its social and economic goals (Mlachila et al. 2016). First used in the British lexicon, the word "financial inclusion" indicates that there was no exclusion from bank accounts of about five million people (Levine 2005).

Financial exclusion is a process that, according to Conroy (2005), is preventing poor and disadvantaged social groups from accessing formal financial systems in their country. According to Mohan (2006), financial exclusion refers to a lack of access to adequate, low-cost, fair, and secure financial products and services offered by traditional providers by certain segments of society. Financial exclusion has generally been defined as a failure of some societies to access the financial systems (although occasionally).

Financial inclusion infers a coordinated effort to deepen financial services among a large number of customers (Carbo et al. 2005). Well-functioning financial inclusion is capable of providing appropriate, low-cost, fair, and secure financial services and instruments, such as bank accounts, affordable loans, assets, savings, and insurance payments, and sending mainstream money advice to everyone (Mohan 2006; Allen et al. 2016). The same views have been articulated in the formal financial system by Oji (2015), who is a proponent of financial inclusion, for those who continue to be excluded from affordable financial services (e.g., access to deposits, loans, insurance facilities, payment, and transfer facility).

The literature also indicates that there are rates of financial exclusion/inclusion. Within the context of the present study, the term "financial inclusion" was described in the light of this discussion as a process that improves availability, improves accessibility, and ensures that all segments of society use basic financial products and services. In view of all these dimensions, the degree of financial inclusion/exclusion is evaluated during the analysis.

\subsection{Background, Content, and Progress Toward Ethiopia's Financial Inclusion Strategy}

Around two-thirds of regulatory and supervisory bodies are now responsible for promoting financial inclusion at the country level. About 50 countries have formally set financial inclusion targets

1 https://www.accion.org/six-things-global-findex-financial-inclusion-progress. 
and objectives in recent years. However, it is not trivial to boost financial integration. The establishment of new bank accounts is not always a regular use. In South Africa, only 3.5 million of those 6 million new accounts mentioned above are active, and the rest are sleeping (World Bank 2012).

Promoting financial inclusion means tackling policy and market challenges leading to financial exclusion. By developing an appropriate regulatory and legal framework, by supporting the information environment, and by training and protecting financial service users, the public sector can promote this objective (Table 1). Any public sector intervention is more effective if the private sector is involved. For instance, improving the credit environment, disclosure methods, and the collateral structure with private sector purchase and support can be more effective (Allen et al. 2016).

Table 1. Main definitions of financial inclusion and exclusion.

\begin{tabular}{|c|c|c|}
\hline Financial Inclusion Definition & Financial Exclusion Definition & Reference \\
\hline \multirow[t]{3}{*}{$\begin{array}{l}\text { Financial inclusion implies equal, open and } \\
\text { inclusive access to finance and financial } \\
\text { services for everyone at reasonable cost }\end{array}$} & & Oji (2015) \\
\hline & $\begin{array}{l}\text { Financial exclusion is a mechanism which } \\
\text { prohibits entry to a structured financial system by } \\
\text { certain social groups and individuals }\end{array}$ & Allen et al. (2016) \\
\hline & $\begin{array}{l}\text { Financial exclusion may be the result of a number } \\
\text { of factors, including financial products that do } \\
\text { not meet the needs of low-income consumers, } \\
\text { high-interest rates and other charges, lack of } \\
\text { information, self-exclusion, disability, } \\
\text { geographical factors and cultural barriers }\end{array}$ & Mohan (2006) \\
\hline
\end{tabular}

The cost and discretion of access to financial services can be cut back by technological innovations. New technologies, like mobile payments, mobile banking, Internet banking, and biometric identification technologies, have been rapidly increasing over the last decade. While the public debate focused largely on mobile payments and mobile banking, other new technologies are promising. Recent research (Kanz 2012; Allen et al. 2016) has shown that biomedical identification can significantly reduce information and moral hazards on credit markets (such as fingerprinting, iris scanning, etc.).

New technologies in different economies have taken a different path. In mobile technology, for example, the development of mobile banking is not dependent on ubiquity or high penetration. In Kenya, where mobile payment services began when the mobile penetration rate of the country was only around 20 percent, we can concentrate on this. This was like the rate at which mobile payments did not develop to the same high level as in countries like Afghanistan, Tanzania, and Rwanda (World Bank 2012).

Ethiopia, although its financial sector has been reformed in recent decades, remains unreliable even with regard to the averages of sub-Saharan African economies and numerous other low-income economies in various parts of the world. The indicator for this is a significant gap in financial inclusion, with adults over the age of 15 holding a financial institution account or a mobile money account representing 22.79\% and approximately 0\% in 2014, respectively (World Bank 2014b). In all financial metrics, including the number of banking branches and ATMs per 100,000 adults and depositors and creditors for 1.000 adults, Ethiopia was substantially behind other sub-Saharan African countries, at 1.3, 0.241, 136.13, and 2.09 in 2012 (International Monetary Fund (IMF) 2014). This inclusion of loans was made a major obstacle by high-targeted lending to public companies, primarily commercial banks in Ethiopia. Besides the reach of the financial industries, bureaucratic and financial challenges often prevent individuals and companies from accessing and using Ethiopian financial services. The suggestion that financial inclusion is simply the opening of an account at a formal financial institution may be refuted. This pure conviction will possibly be based on the fact that the opening account does not 
alter household lives. A similar finding by Beck (2010) indicates that greater financial inclusion speeds up economic growth, increases competition, and boosts demand for labor. Those people at the lower end of the income continuum should benefit comparatively more and therefore achieve healthy growth.

\subsection{Empirical Literature}

A variety of models to identify financial inclusion barriers have been proposed. In general, there is a consensus on the presence of barriers to supply and demand. The literature on the supply side discusses how the structure, establishment, and accessibility of financial institutions contribute to the unbanked status of some households. Most (poor) households will be borrowing for needs that are non-returnable, such as healthcare and marriages. This may make banks unwilling to borrow because a payback guarantee is not available (Johnson and Arnold 2012).

Another barrier is the definition of the core against the non-core business. In developing countries, the poor may be interested in payments and remittances. However, credit is what most banks consider to be a key, and interest rate ceiling financial regimes have supported this idea as well (Johnson and Arnold 2012). In order to guarantee everyone's inclusiveness, the traditional role of banks in developing markets must be challenged.

Transactions by the poor may be small in size, which means that the high burden of variable or fixed cost cannot be carried by each transaction (Demirguc-Kunt et al. 2015). The need for institutions to reach the unbanked may be affected by weak systems, i.e., legal and information infrastructure. These weak systems enhance the risk and costs of services and thus economically unrealistic business proposals. Failures on the market, such as asymmetric information, monopoly of financial markets, or oligopoly and accessibility barriers for new competitors are obstacles to part of the population which are excluded due to prices, risks, and lower supplies (Zins and Weill 2016). Other determinants of supply-side include branch distance, branch times, language, staff position, and tedious documentation and procedures. In general, supply-side factors increase transaction costs, which are a significant effect.

The predominant barriers to access financial services on the side of demand are prices and incomes (Efina 2016). The low level of literacy (financial) leads to lower demands on formal service providers (Efina 2016; Morgan and Trinh 2019). When financial infrastructure is less developed, formal financial services are expected to be unavailable. This is especially serious in Africa because in some countries remote populations are anticipated. As Mlachila et al. (2016) pointed out, the gaps in financial inclusion have sometimes been covered by new financial services such as mobile payment systems and mobile banks, especially in East Africa and in particular those relating to economic status and gender. More specifically, women will contribute to growth not only through the establishment of businesses but also through better management of their financial resources. Access and use of a range of financial services not only enhance the contribution to the growth of women and women-led companies but also helps female empowerment, uses their personal and home resources more effectively, and reduces their household's and companies' vulnerability (World Bank 2017). Briefly, closing the gender gap in financial inclusion can be an impulse for country development, economic growth, reduction of inequalities, business development, and social inclusion. However, women's financial inclusion calls for a more gender-based, inclusive financial system that addresses the specific barriers to demand and supply for women. It is also applicable to a regulatory inclusive environment (GCAP 2017). It is important to recognize that wider social constraints associated with intra-domestic negotiations and the social status of women limit the greater impact of financial inclusion on the empowerment of women. It is also applicable to a regulatory inclusive environment (GCAP 2017). It is also important to recognize that wider social constraints associated with intra-domestic negotiations and the social status of women limit the greater impact of financial inclusion on the empowerment of women (GCAP 2017).

Any challenges hampering efforts at the state or federal level toward financial inclusion are even more pronounced in rural areas (Calderón and Liu 2003). Users have limited financial capacity that limits demands, while financial institutions provide services that are not entirely tailored to people's needs (Beck et al. 2007). The literature illustrates the relationship between the rural populations and 
financial inclusion, thus assessing factors influencing financial inclusion indexes (Ford and Rowlingson 1996). Yorulmaz (1996) findings show a negative relationship between the rural population and financial inclusion. He acknowledges with the general observation that financial inclusion levels decrease as one goes into rural parts of a country.

According to previous investigations, around 7.1 million customers had savings accounts in Ethiopian banks in 2013. It constitutes $8 \%$ of the population as a whole. Bank lenders are mainly big and old businesses. Sinha and Subramanian (2007) concluded that a shortage of steady income is the leading cause of financial exclusion in Ethiopia. The small income does not provide them with any reason to set up a savings account, so they are not liable for a mortgage. The proportion of people living below the poverty line certainly affects the rate of economic exclusion (Oji 2015). Sarma and Pais (2008) concluded that revenue is an important element for evaluating the level of financial inclusion of a country as a per capita GDP measure and that family's economic status is positively related to financial inclusion levels.

Participation in the financial system is less common for the disabled, those with erratic earnings, and those with insecure jobs. In the UK, payment of wages by electronic cash transfer has been identified as promoting financial inclusion (Babajide et al. 2015). The informal economy accounts for a significant proportion of workers in less developed countries such as Ethiopia. Traditional employment in the world includes involvement in traditional financial systems in which salaries and profits are channeled through the structured banking system.

\section{The Current Status of Ethiopia's Financial Inclusion}

As described by the Zins and Weill (2016), Ethiopia's financial sector is shallow, and the financial services penetration is still weak. World Bank (2014b) reported that less than $10 \%$ of households had exposure to structured loans and in 2014, just $22 \%$ of the population had a balance (Zwendu 2014). This is below the 34 billion sub-Saharan norm. Lack of physical connectivity is one of the major problems in improving financial inclusion. While the number of bank branches has risen nearly fourfold over the past 12 years to 1376 in 2012/13, the population size per branch is still very small $(1: 61,628)$. There are common informal financial transactions. However, nearly all farmworkers (97.3 million) received cash payments for agricultural products, while only $0.5 \%$ received payments on the account. Rather than using banks, microfinance institutions (MFIs), or savings and credit cooperative organizations (SACCOs), rural households usually save in money. These communities also have a strong perception that they have insufficient funds to use regulated financial services (World Bank 2014b).

Two of the most important informal financial institutions in Ethiopia, Iqub and Edir, have remained at the heart of anthropologists and sociologists' analysis. In Ethiopia, small and medium-sized enterprises routinely raise funds from the informal financial sector. Most notably, the informal financial sector is dominated by Iqub schemes (indigenous financial associations in which financial contributions are routinely collected from fellow members at regular intervals and paid out as a lump sum, interest-free, to one member of the scheme at a time) (Demirguc-Kunt et al. 2015). Formal saving and lending institutions are not used to the vast majority of the Ethiopian people. The few banks and credit organizations currently in operation in the country are restricted to urban areas, while over $80 \%$ of the population lives in rural areas. In addition, these banks are not much used by even the urban population. The problem now is, "Why is the population not successfully using the formal sector?" First of all, it should be noted that households have low saving power, primarily due to the country's low per capita income. In fact, the country's political and social environment is not adequately conducive to savings mobilization. To be specific, the informal financial sector, as shown by studies undertaken in developing areas (Zwendu 2014; Demirguc-Kunt et al. 2015; Baza and Rao 2017), has certain advantages over the formal sector. The average size, for example, and cost for loan and recovery are very low. Free entry, exit, and independence from the influence of de jure and de facto central banking; knowledge collection is minimized, while trust and first-hand experience are significant (Baza and Rao 2017).

In Ethiopia, the process closure for foreign companies often implies lost equity investment incentives, foreign currency entry, banking technologies, and expertise. To date, there are no investment 
banks, and a cash-based system governs financial services. The lack of a traveling collateral database, except for cars, is an additional key restriction in Ethiopia's current banking system. Small businesses cannot use their digital assets to access mortgages and financial institutions. They find it difficult to diversify their resources, and this results in poor risk management activities. Collateral databases can boost financial sector competitiveness by allowing both banks and non-bank financial institutions to provide stable borrowing.

A large majority of Ethiopians are not planning for the future so in a crisis, it is difficult to raise funds (Babajide et al. 2015). Nevertheless, Ethiopia's geographical position, topography, high poverty levels, and strong dependency on rain-fed agriculture for livelihood and income generation are extremely linked to weather fluctuations and transition. Only 23\% of the Ethiopian population saved for the future (for old age, running, or expanding a farm or company) in 2014. This is partly due to the large proportion of Ethiopians who live in poverty. Women also save less than the average population (15\%) to begin, run, and grow their farms or companies (Ngweno et al. 2018). The failure to save people affects their ability to cope with crises. For example, in 2014, 38\% said that emergency funds could not be built very well. This figure is up to 45 million for women. $41 \%$ of the population claim that family or friends are the primary sources of funding in a crisis, along with a financial institution or the use of a credit card (only 1\%) (World Bank 2014a, 2015; Demirguc-Kunt et al. 2015).

As shown in Figure 1, there is no microfinance institutions (MFI) in the area of Afar in Ethiopia. Although the MFIs have helped to hit the unbanked community, especially the poor, through mobilizing deposits, loans, and to some degree micro-insurance products, the distribution in Ethiopia is still less widespread. In 1996, the Government of Ethiopia released Proclamation 40/1996 authorizing MFIs to be created. Thirty-one MFIs were founded from in 1998/1999 up to 2014 (Zwendu 2014). Fourteen (47\%) of all MFIs work in Addis Ababa. MFIs currently have 1385 branches and sub-branches in various parts of the country. This is still very low in terms of consumer service rate, i.e., one branch for 61,228 adults. In 2011 , it was reported that MFIs had only affected $14.5 \%$ of the country's households, which indicates that most people still do not have access to financial services.

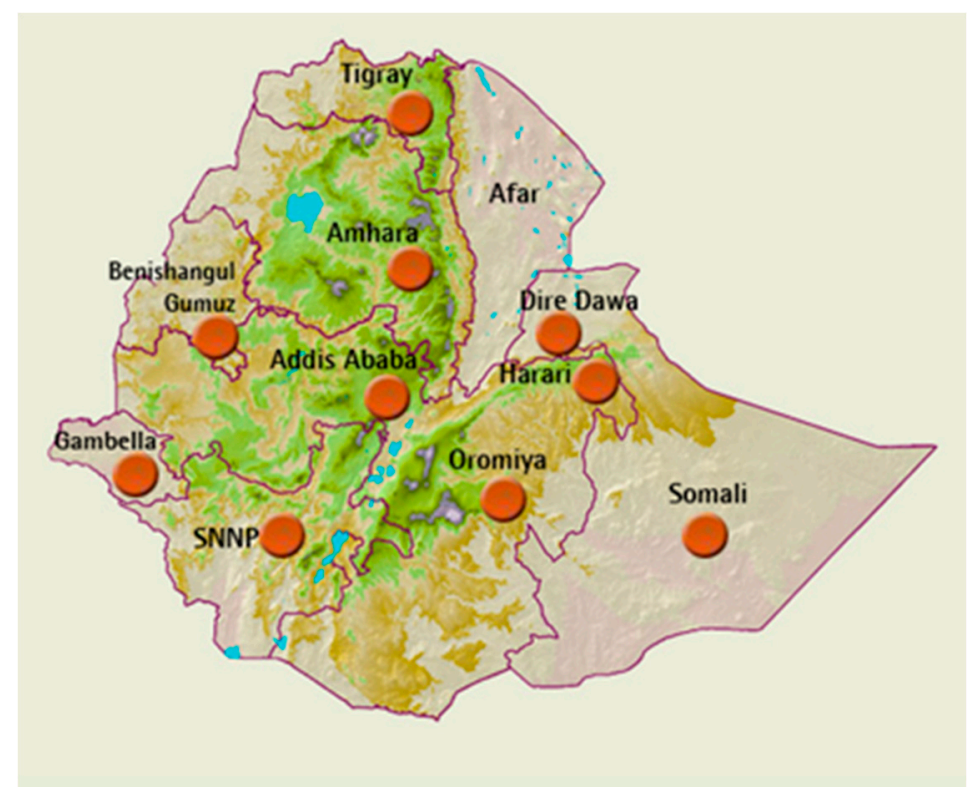

Figure 1. Microfinance institutions (MFI) distribution in Ethiopia. Source: association of Ethiopian MFIs (cited in a study by Babajide et al. 2015).

\section{Exploring the Main Challenges and Possibilities}

Despite the recent year's improvement, the serious problem in Ethiopia is still unemployment. The 2013 survey of Ethiopia's national labor force shows that unemployment is 5\% in Ethiopia. Female 
youth have a higher rate $(6.5 \%)$ compared to male youth $(2.7 \%)$. Unemployment is a major challenge that affects people's daily activities (Beck et al. 2007; Desalegn and Yemataw 2017).

Supporting MSEs is the driving force behind job creation, incorporation, and the promotion of self-employment for the unemployed. Although efforts have been made to promote MSEs, Ethiopia is known as the 150th country in terms of challenges to people's access to credit, even in rural areas (Desalegn and Yemataw 2017).

According to World Bank (2017), however, the number of adults who have an account has risen from $22 \%$ in 2014 to $35 \%$. The use of the account has also increased. Today, $26 \%$ of adults are investing in financial institutions (14\% in 2014), and $11 \%$ are borrowing from financial institutions (7\% in 2014).

Female managed businesses in Ethiopia face further restrictions on access to finance (GCAP 2017). Nearly half of female-managed companies consider financial exposure as a significant limitation relative to $19 \%$ of male-managed firms. In Ethiopia, most developing-oriented women entrepreneurs are unable to move from team lending to larger, personal loans that can support business growth. In terms of individual characteristics, women's access is very low compared to men, as only $29.1 \%$ of women in Ethiopia have formal accounts at formal financial institutions. Based on a study by Dinku (2019), women account for a disproportionate share of non-bank account, and the gap is growing, with the gender gap rising to $12 \%$ in 2017 from virtually insignificant in 2014. Currently, $41 \%$ of individuals and $29 \%$ of females have a bank account, compared with $23 \%$ of males and $21 \%$ of women who had an account in 2014, which were essentially equivalent. There appears to be little barrier to the cost of financial services, which is quoted by only $5 \%$ of adults without an account. This cannot be shocking as banks and MFIs offer basic financial transactions such as opening an account and making deposits and withdrawals free of charge. The minimum account balance is from 25 ETB to 50 ETB, with the exception of the 25,000 ETB at Zemen Bank.

\section{Discussion}

\subsection{Determinants of Financial Inclusion Indicators}

The main barriers to access financial services are price and income on the side of demand (United Nations Development Programme (UNDP) 2014). The low level of literacy (financial) leads to lower demand for formal service suppliers. In cases where financial infrastructure is less developed, formal financial services are expected to be unavailable (Ford and Rowlingson 1996). This is especially important in Africa since in some countries, remote populations are expected.

While measuring factors that influence financial inclusion indices, the literature points to the relationship between the rural population and financial inclusion. Findings by Yorulmaz (2016) indicate a negative relationship between the rural population and financial inclusion. He concurs with the general observation that as one goes into rural parts of a country, financial inclusion levels decrease. There are fewer bank branches in rural areas, and even these branches are spread far and thin. A bleak example is rural Madagascar where there exists one bank branch for 1.4 million people. This goes parallel with this research's findings. In Addis Ababa, the capital city of Ethiopia, anyone can find a bank every 1.5 K.M., whereas there is no bank in remote areas (Ethiopian Central Statistical Authority 2010; World Bank 2014a).

Research on economic exclusion reflects the broader problem of social exclusion. Studies show that people in low-income groups, ethnic minorities, and the elderly are excluded from the formal financial system. The low-income countries have high financial inclusion rates system, those with irregular incomes and those with insecure jobs. In the UK, salary payments have been defined as promoting financial inclusion through automatic cash transfer. The provision of social security benefits and government pensions have been a significant source of financial exclusion (Ford and Rowlingson 1996).

The informal economy accounts for a large percentage of the population in less developed countries. World public sector employment means inclusion in the formal financial system because the structured banking system is used to funnel wages and salaries. A good indicator of the degree 
of financial inclusion is the percentage of formal sector jobs. Findings of Yorulmaz (2016) suggest that the economic inclusion of poverty is negative, and therefore the risk of unemployed people and irregularities being officially listed is less high.

\subsection{Determinants of Barriers to Financial Inclusion}

Account ownership barriers indicate that jobs, education, class, government change, and savings affect barriers to financial inclusion and are considered significant at various levels in sub-Saharan Africa (Adeola and Evans 2017). Being in the wealthiest 20\% tax quintile group ensures that it is not a major problem to be too far from the financial services company. The wealthy citizens have more mobility, and therefore, distance is not a significant consideration (Adeola and Evans 2017). However, the findings show that most of the above items have had an impact on lack of paperwork, lack of trust in financial institutions and ethnicity (World Bank 2015). Such results provide a perspective in line with the current state of mobile phone account possession. It is interesting, however, that there are some people who view cell phone accounts as "hard to get" as shown by the "no access" barrier (Allen et al. 2016).

\subsection{How to Make Resilient Financial Services in Ethiopia Resilient?}

Low-income households around the world are particularly vulnerable to shocks. They are the least prepared when there is a shock. Another threat factor for fragile families is caused by the consequences of climate change, including hurricanes, droughts, and other weather conditions. In this sense, it is becoming increasingly important for poor households to develop resilience to improve their ability to mitigate, cope with, and rebound from shocks and pressure without sacrificing their potential welfare. The evidence suggests that well-designed economic products and services can help low-income families boost their resilience by encouraging them to prepare for risks, reduce risks, increase investment in threats, and react when shock strikes occur (Jiang and Peng 2011). Nonetheless, the role that financial products and services can play in this sustainability and the most efficient production and distribution processes are not fully understood.

A crucial step is to reinforce the climate, enabling increased financial inclusion and scope. Governments will need to strengthen regulatory and legal systems to make them more open and coherent, cut costs, and simplify market entry requirements. On the demand side, they need more security for consumers and better physical access for the most disadvantaged groups (Baza and Rao 2017). This will enhance market competition, efficiency, and confidence in the banking system. International development partners and sponsors can, in turn, provide financial service companies with economic, legal, and technical assistance to allow them to grow and expand services at a cost that is affordable and to offer services that promote an ethical approach to risk management in decision-making (World Bank 2015).

\subsection{Enhancing Access and Simplifying Requirements for Market Entry}

Finance will help people improve their wages, protect against risks, and increase opportunities for investment. Much of the current study highlighted the importance of total financial growth. Nevertheless, banking systems and capital markets often are biased towards those who are well off, primarily catering to large companies and rich individuals, especially in developing countries (Amidžic et al. 2014). Bank access is not equivalent to access to financial services. With regard to the objective standard, access refers to the provision of a reasonable quality of financial services at a reasonable cost, where reasonable quality and cost have to be calculated, and costs represent both financial and non-cash usages (UNCDF 2006). The lack of institutional capacity to provide financial services was historically considered to be a major bottleneck for the poor in terms of access to finance. Funders, therefore, provided financial and technical support to the most significant part of the funding allocated to support portfolio growth in order to support the development and growth of financial service providers (Lahaye, Estelle, and Dashi Edlira 2015). While this provider-oriented approach to institution-building helped to increase financial inclusion, the underlying restrictions were not addressed. Funder support 
paid too little attention to understanding customer needs, fostering regulatory environments, and strengthening market infrastructure, all necessary to create the right mechanisms for the development of various mechanisms, incentives, tools, and controls. At the same time, many providers of financial services continue to rely on grants, which also raise concerns about sustainable long-term access (Karpowicz 2014).

In this context, the relevance and applicability of the approach to financial inclusion of market access programs is becoming increasingly debated among donors. This strategy applies to the entrance of financial services on the market and their use. Poor and low-income people are financial services users and are connected with financial service providers to access and use financial services. In order to support the core exchange between supply and demand, multiple market operations (supporting functions, rules, and standards) are required. A number of market players, public and private alike, carry out these functions through their own capabilities and incentives. The approach to financial inclusion in market systems aims to change the dynamics of this multi-functional, multi-actors' structure for the benefit of the poor. Therefore, when financial service providers adopt new technology and solutions, policymakers will need to enforce policies to ensure that potential users have the required skills and have key enablers for accessing and using those products (e.g., national IDs and mobile phones) (GSMA 2014).

In addition, regulators have an important role to play in catalyzing or impeding progress towards financial inclusion in the country. The Global Microscope defines and discusses the existing policies and regulations of each country by analyzing five regulatory domains across 55 countries (i.e., government and policy implementation, stability and credibility, goods and markets, consumer protection, and infrastructures). The major points highlighted by the Global Microscope are as follows: (1) policymakers must ensure that both women and men are empowered and enabled to utilize benefits from greater financial inclusion. (2) Governments must ensure that their national strategies do not worsen the gender gap ${ }^{2}$.

\section{Conclusions and Policy Implications}

Despite the fact that over the last few years, Ethiopia has achieved rapid growth in the financial sector, many households are still excluded from access to the necessary financial services. According to the results, individuals have rather little access to financial services, and only a small number of individuals have an account with formal financial institutions. In order to encourage financial inclusion in terms of investments, the results of this paper indicate that financial literacy services are necessary to allow individuals to know their financial circumstances. Formal savings are more likely to be made by individuals who keep track of their financial situation. The main policy implication of these findings is that keeping a financial diary could result in savings because people are more conscious of their expenses and tend to spend more thoroughly and reduce costs. Additionally, encouraging individuals to keep financial diaries to record their income and expenses may result in increased formal personal savings. Initiatives of financial education that teach financial skills to participants, such as managing financial diaries, can improve the low savings rate in countries with a high level of literacy, like Ethiopia.

This paper argues that organized financial access, such as more branches of financial institutions providing investment products, could be improved by having adequate services. Nevertheless, Ethiopia lags in this way behind sub-Saharan Africa and low-income economies. The key barriers to this are a lack of sufficient resources, distance, cost, and documentation requirements. Improving access to public transit, which could extend the reach of official financial institutions by encouraging more people to physically access financial institutions, is a practical policy to address that issue. Public transit access may also be extended by allowing more people to directly contact financial institutions.

2 https://www.centerforfinancialinclusion.org/global-microscope-2019. 
Finally, the findings regarding individuals' access to and use of financial services identified physical, bureaucratic, and financial barriers. Therefore, this paper suggests that some networks can facilitate access, including the use of local banks such as trucks and transportation to provide connectivity to remote regions and the establishment of mobile banking infrastructure. Such instances were introduced in other countries and helped extend the access of formal financial services to remote communities, without easy access to public or formal financial institutions.

Furthermore, the findings of this paper indicate that low savings rates in Ethiopia were primarily caused by inflation and income pressures at both official and informal scales. This indicates that initiatives seeking to increase Ethiopia's savings rates must address the issue of matching revenue-expenditures. Supplementary income measures such as skills training could be given based on the target population. Research in other countries shows that designing effective savings services tailored for low-income groups can help address the saving problem. Services for supporting low-income earners have been shown to help increase spending on a regular basis. Substantial improvements are expected in the financial sector and in the social and economic factors for the next few years in order to promote financial inclusion in Ethiopia along with economic progress.

With rapid growth, profits are rising, and efforts to promote financial inclusion are gradually offering services to low-income individuals to a larger number of financial entities. This, coupled with policies that come from careful analysis of financial inclusion's demand side, will pave the way for expanded savings in Ethiopia and allow people who had previously been exempted to access structured savings goods. Finally, to highlight recommendations from this study, the identification and addressing of root causes appears to remove barriers to distance, cost, credit, and documentation. Nevertheless, market failures and behavioral issues tend to be addressed by designing appropriate financial products. With the promise of new technologies, the elimination of challenges and expansion of financial inclusion tends to be possible. For example, mobile payments, mobile banking, and the use of biometric devices can reduce costs, speed up transfers, and increase the security of household transactions.

Author Contributions: T.B.L. came up with the main idea and developed the main text; H.A. provided instruction and comments for enriching the first draft, and also helped the first author to address the reviewers' comments. All authors have read and agreed to the published version of the manuscript.

Funding: This paper received no findigns from any orgranizations.

Conflicts of Interest: The authors declare no conflict of interest.

\section{References}

Adeola, Ogechi, and Olaniyi Evans. 2017. Financial inclusion, financial development, and economic diversification in Nigeria. The Journal of Developing Areas 51: 1-15. [CrossRef]

Allen, Franklin, Asli Demirguc-Kunt, Leora Klapper, and Maria Soledad Martinez Peria. 2016. The Foundations of Financial Inclusion: Understanding Ownership and Use of Formal Accounts (English). Policy Research Working Paper No. WPS 6290. Washington, DC: World Bank Group. [CrossRef]

Amidžic, Goran, Alexander A Massara, and Ander Mialou. 2014. Assessing Countries' Financial Inclusion Standing: A New Composite Index. IMF Working Papers No. 14. Washington, DC: International Monetary Fund.

Babajide, Abiola A., Folasade B. Adegboye, and Alexander E. Omankhanlen. 2015. Financial Inclusion and Economic Growth in Nigeria. International Journal of Economics and Financial Issues 5: 629-637.

Baza, Andualem Ufo, and Sambasiva Rao. 2017. Financial Inclusion in Ethiopia. International Journal of Economics and Finance 9. [CrossRef]

Beck, Thorsten. 2010. Financial development and economic growth: Stock markets versus bank. Private Sector $\mathcal{E}$ Development 5.

Beck, Thorsten, and Robert Cull. 2015. Banking in Africa. In The Oxford Handbook of Banking. Edited by Allen N. Berger, Philip Molyneux and John O. S. Wilson. Oxford: Oxford University Press, pp. 913-37.

Beck, Thorsten, Asli Demirgüç-Kunt, and Ross Levine. 2007. Finance, inequality and the poor. Journal of Economic Growth 12: 27-49. [CrossRef]

Calderón, César, and Lin Liu. 2003. The direction of causality between financial development and economic growth. Journal of Development Economics 72: 321-34. [CrossRef] 
Carbo, Santiago, Edward Gardner, and Philip Molyneux. 2005. Financial Exclusion. Lundon: Palgrave MacMillan. Collins, Daryl, Jonathan Morduch, Stuart Rutherford, and Orlanda Ruthven. 2009. Portfolios of the Poor: How the World's Poor Live on \$2 a Day. Princeton: Princeton University Press.

Conroy, John. 2005. APEC And Financial Exclusion: Missed Opportunities for Collective Action? Asia-Pacific Development Journal 12: 53-79. [CrossRef]

Demirguc-Kunt, Asli, Leora Klapper, Dorothe Singer, and Peter Van Oudheusden. 2015. Measuring Financial Inclusion around the World: The Global Findex Database (2014). Policy Research Working Paper 7255. Washington, DC: World Bank. [CrossRef]

Desalegn, Gashaw, and Gebe Yemataw. 2017. Financial Inclusion in Ethiopia: Using LSMS (Ethiopia Socioeconomic Survey) Data. Ethiopian Journal of Economics 26: 31-58.

Dinku, Tirngo. 2019. Financial inclusion in Ethiopia: Using core set of financial inclusion indicators. Journal of Research and Opinion. [CrossRef]

Efina. 2016. Financial Inclusion. Available online: http://www.efina.org.ng/about-us/financial-inclusion/ (accessed on 21 March 2016).

Ethiopian Central Statistical Authority. 2010. Annual Report for the Year 2010. Addis Ababa: Ethiopian Central Statistical Authority.

European Commission. 2008. Financial services Provision and Prevention of Financial Exclusion. Report by the Director General for Employment, Social Affairs and Equal Opportunities. Brussels: European Commission.

Ford, Janet, and Karen Rowlingson. 1996. Low-income households and credit: Exclusion, preference and inclusion. Environment and Planning A 28: 1345-60. [CrossRef]

GCAP. 2017. Social Norms Change for Women's Financial Inclusion. Available online: http://www.cgap.org/ sites/default/files/Brief-Social-Norms-Change-forWomens-Financial-Inclusion-Jul-2017_0.pdf (accessed on 21 July 2017).

GSMA. 2014. State of the Industry. Mobile Financial Services for the Unbanked. Available online: http://www.gsma. com/mobilefordevelopment/wp-content/uploads/2015/03/SOTIR_2014.pdf (accessed on 1 March 2015).

International Monetary Fund (IMF). 2014. Article IV Consultation Staff Report; Press Release; and Statement by The Executive Director for The Federal Democratic Republic of Ethiopia. IMF Country Report No. 14/303. Washington, DC: IMF, Available online: https://www.imf.org/external/pubs/ft/scr/2014/cr14303.pdf (accessed on 25 October 2014).

Jiang, Yi, and Mike W. Peng. 2011. Are family ownership and control in large firms good, bad, or irrelevant? Asia Pacific Journal of Management 28: 15-39. [CrossRef]

Johnson, Susan, and Steven Arnold. 2012. Inclusive financial markets: Is transformation under way in Kenya? Development Policy Review 30: 719-48. [CrossRef]

Kanz, Martin. 2012. What Does Debt Relief Do for Development? Evidence from India's Bailout Program for Highly Indebted-Rural Households. Policy Research Working Paper 6258. Washington, DC: World Bank.

Karpowicz, Izabela. 2014. Financial Inclusion, Growth and Inequality: A Model Application to Colombia. No. 14-166. Washington, DC: International Monetary Fund.

Lahaye, Estelle, and Dashi Edlira. 2015. Spotlight on International Funders' Commitments to Financial Inclusion. Brief. Washington, DC: CGAP, Available online: http://www.cgap.org/publications/spotlight-internationalfunders-commitmentsfinancial-inclusion (accessed on 25 March 2015).

Levine, Ross. 2005. Finance and growth: Theory and evidence. Handbook of Economic Growth 1: 865-934.

Mlachila, Montfort, Larry Cui, Ahmat Jidoud, Monique Newiak, Bozena Radzewicz-Bak, Misa Takebe, Yanmin Ye, and Jiayi Zhang. 2016. Financial Development in Sub-Saharan Africa: Promoting Inclusive and Sustainable Growth. Washington, DC: International Monetary Fund.

Mohan, Rakesh. 2006. Economic Growth, Financial Deepening and Financial Inclusion, Address at the Annual Bankers' Conference 2006, Hyderabad on November 3. Available online: http://rbidocs.rbi.org.in/rdocs/ Speeches/PDFs/73697.pdf (accessed on 10 November 2006).

Morgan, Peter J., and Long Q. Trinh. 2019. Determinants and Impacts of Financial Literacy in Cambodia and Viet Nam. Journal of Risk and Financial Management 12: 19. [CrossRef]

Ngweno, Amolo, Lauren Oldja, Michelle Hassan, and Priyanka Kapoor. 2018. Demand-Side Review of Financial Inclusion for Women in Entrepreneurship and Smallholder Agriculture. IDRC: forthcoming.

Oji, Chijioke Kennedy. 2015. Promoting Financial Inclusion for Inclusive Growth in Africa: South African Institute of International Affairs. Johannesburg: SAIIA. 
Sahay, Ratna, Martin Čihák, Papa M’Bagnick Paté N’Diaye, Adolfo Barajas, Srobona Mitra, Annette Kyobe, Yen Nian Mooi, and Seyed Reza Yousefi. 2015. Financial Inclusion: Can It Meet Multiple Macroeconomic Goals? IMF Staff Discussion Note 15/17 September. Washington, DC: IMF.

Sarma, Mandira, and Jesim Pais. 2008. Financial Inclusion and Development: A Cross Country Analysis. Journal of International Development 23.

Sinha, Janmejaya, and Arvind Subramanian. 2007. The Next Billion Consumers-Boston Consulting Group's Report. Available online: http://www.cab.org.in/ICTPortal/Lists/Knowledge\%20Bank/Attachments/8/The_ Next_Billion_Banking_Customers_Nov_07.pdf (accessed on 4 October 2012).

UNCDF. 2006. Building Financial Inclusive Financial Sectors for Development. New York: United Nations Capital Development Fund.

United Nations Development Programme (UNDP). 2014. National Human Development Report_Ethiopia. Addis Ababa: UNDP.

World Bank. 2012. Financial Inclusion Strategies Reference Framework. Prepared for the G20 Mexico Presidency. Washington, DC: World Bank.

World Bank. 2014a. Global Financial Inclusion (Global Findex) Database. Washington, DC: World Bank Group. Available online: http://datatopics.worldbank.org/financialinclusion/country/ethiopia (accessed on 15 April 2015).

World Bank. 2014b. Global Findex 2014. Regional Portraits of Universal Progress: Sub-Saharan Africa. Washington, DC: World Bank.

World Bank. 2015. Enterprise Surveys. Washington, DC: The World Bank, Available online: http://www.enterprisesurveys. org/data/exploreeconomies/2015/ethiopia\#firm-characteristics (accessed on 17 August 2016).

World Bank. 2017. The Global Findex Database. Washington, DC: World Bank, Available online: http://documents. worldbank.org/curated/en/332881525873182837/The-Global-FindexDatabase-2017-Measuring-FinancialInclusion-and-the-Fintech-Revolution (accessed on 19 April 2018).

Yorulmaz, Recep. 2016. Construction of a Financial Inclusion Index for the Member and Candidate Countries of the European Union. Project: Financial Inclusion Index. Available online: https://mafiadoc.com/91-constructionof-a-financial-inclusion-index-for-the-member-saytay_5a13b1191723ddeb8bbbd3bf.html (accessed on 22 August 2017).

Zins, Alexandra, and Laurent Weill. 2016. The determinants of financial inclusion in Africa. Review of Development Finance 6: 46-57. [CrossRef]

Zwendu, GA. 2014. Financial Inclusion, Regulation and Inclusive Growth in Ethiopia. Working Paper 408. London: ODI. 